\title{
WOMEN, GENDER, AND THE KIRK BEFORE THE COVENANT
}

\author{
Jason Cameron White, Appalachian State University
}

\section{ABSTRACT}

This article explores the ways women interacted with the Scottish kirk in the decades prior to the National Covenant of 1638, mainly focusing on urban areas especially Edinburgh and environs. The written records, especially those of the kirk session, are skewed toward punishing women who engaged in sin, especially sexual sins such as adultery and fornication. Indeed, these records show that while women's behavior and speech was highly restricted and women were punished more frequently than men for their sexual behavior or for speaking out of turn, there were moments when women had a significant public voice, albeit one that was highly restricted and required male sanctioning. For example, women were often called on to testify before kirk sessions against those who had committed sins, even if the accused sinners were male or social superiors or both. Perhaps the most important moment where women used their male-sanctioned voice to speak out in public came at the Edinburgh Prayer Book Riots of 1637, which was led by women. This article argues that women were given the opportunity to act in public because the church had been characterized by many Scottish male preachers in gendered language - they called the church a "harlot mother" and a "whore" that needed correction. Therefore, the women of the Prayer Book Riot were sanctioned to speak out against a licentious sinner, much in the way women were called on to testify against sinners in front of kirk sessions.

Keywords: Scotland, women, gender, Scottish Kirk, National Covenant, $17^{\text {th }}$ century 


\section{Introduction}

Perhaps the most significant and well-known instance of women taking a public and political role in early seventeenth century Scotland was the Edinburgh Prayer Book Riot of 1637, in which female voices, sanctioned by male authority, called out the perceived sins of the kirk and shamed their social superiors for their role in facilitating these sins. This was a seminal moment in Scottish history as these female-led riots led to a series of events that culminated in the drafting and signing of the National Covenant in early 1638, thereby initiating a lengthy period of civil war in the Stuart kingdoms. This article uses kirk session records and sermons to analyze various aspects of Scottish society and religious life leading to this unusual and important moment. This study mainly focuses on the parishes of Edinburgh and its environs (with a few other urban Lowland parishes included to broaden the source base) in order to gain a deeper sense of women's place within the social, communal, and religious concerns of Edinburgh and urban Lowland Scotland before the Prayer Book Riot of 1637 and the National Covenant of 1638.

These regional sources reveal three things that contributed to female participation in the Riots. First, there was deep concern about female sexual behavior that was intensified by the presence of soldiers from all over Scotland gathering in Lowland towns and cities, such as Edinburgh, on their way to fight on the Continent in the Thirty Years' War. Second, these concerns coincided with another important aspect of women's public role in early modern Scotland-women's voices were constrained, their speech often punished, but there were moments when women could speak publicly with male sanctioning. These moments typically came when women testified in kirk sessions to the sins of others, even if those they accused were above them in the social and gender hierarchy. Third, the obsession with sexual transgressions can be seen in the language of male critics of the Jacobean and Carline changes to the Scottish kirk. This language of "whoredom" and "harlotry," when combined with common Biblical tropes, created a sharp language of criticism that was gendered in its nature. The combined analysis of these three things - a heightened concern over sexual sins caused by 
societal disruption, male-sanctioning of female voices under certain circumstances, and a gendered language of criticism leveled at changes in the kirk - can lead to a better understanding of why and how women were at the forefront of the 1637 Edinburgh Prayer Book Riots, one of the most important events of seventeenth-century Scotland.

This article will build on several important studies about women in early modern Scottish society and, more specifically, women and kirk sessions. Much work has been done in this field, including pioneering work by Elizabeth Ewan, Michael Graham, David Mullan, and others. ${ }^{1}$ However, there have been some differing conclusions on the topic. Some scholars have argued that kirk sessions were mostly concerned with individual cases and therefore gender was not always a main concern in how sessions approached each case. Michael Graham has argued that because sessions held individuals responsible for their behavior, this "militated against the maintenance of any double standard in the area of sexual ethics." Gordon Desbrisay disagrees, remarking that there was indeed a

\footnotetext{
${ }^{1}$ See for example: Elizabeth Ewan, "A New Trumpet? The History of Women in Scotland 1300-1700," History Compass 7, no. 2 (March, 2009): 431-46; Elizabeth Ewan, "Disorderly Damsels? Women and Interpersonal Violence in Pre-Reformation Scotland," The Scottish Historical Review 89, no. 228 (2010): 153-71; Sarah Dunnigan and Elizabeth Ewan, "Introduction: A Century of Disorder and Transformation - Scotland 1550-1650" Renaissance and Reformation / Renaissance Et Réforme 30, no. 4 (2007): 3-12; Michael Graham, The Uses of Reform: Godly Discipline and Popular Behaviour in Scotland and Beyond, 15601610 (Leiden: Brill, 1996), ch. 8; D. Mullan, "Women in Scottish Divinity, c. 1590-c.1640," in Women in Scotland, c. 1100-c.1750, eds. E. Ewan and M. Meikle (East Linton: Tuckwell Press, 1999), 32; D. Mullan, "Scottish Women's Religious Narrative, 1660-1720: Constructing the Evangelical Self," in Women and the Feminine in Medieval and Early Modern Scottish Writing, eds. Sarah M. Dunnigan, C. Marie Harker, and Evelyn S. Newlyn (New York: Palgrave, 2004), 178-194; D. Mullan, Narratives of the Religious Self in Early-Modern Scotland (Burlington, VT: Ashgate, 2010).

${ }^{2}$ M. Graham, "Women and the Church Courts in Reformation-Era Scotland" in Women in Scotland c. 1100-1750, eds. E. Ewan and M. Meikle (East Linton: Tuckwell Press, 1999), 196.
} 
sexual double standard in cases before kirk sessions and that the "war on sin was foremost a war on women." 3 More recently, Alice Glaze has provided a more nuanced picture of women and kirk sessions in her study of the Canongate kirk session. Glaze argues that women's relationship with the kirk session in Canongate was "multifaceted, contradictory, and shifting" and that there were often wider cultural factors at work that could make a woman vulnerable or that she could conversely use to her advantage. ${ }^{4}$ This article builds on Glaze's analysis of Canongate by bringing in other parishes from the Edinburgh region in order to show the complexity of women's interactions with kirk sessions in the $1620 \mathrm{~s}$ and $1630 \mathrm{~s}$ and culminating with the Prayer Book Riots of 1637. Social upheaval caused by soldiers led to concerns about women's sexual interactions with these soldiers. Women ended up in front of kirk sessions for their liaisons with soldiers more frequently and were punished more harshly than the soldiers, mainly because the soldiers were often gone and the women left with their illegitimate children. Nevertheless, women in these decades played an important role in testifying against the sins of others.

\section{Section I: Women, Soldiers, and Kirk Sessions Before the Covenant}

Kirk sessions were a standard feature of the post-Reformation parish in Lowland Scotland. They were church courts at the parochial level, tasked with monitoring the behavior of everyone within the bounds of the parish, and, when sinners were "discovered," fining them, admonishing them to repent, and sometimes handing them over to secular authorities for corporal punishment (and often the secular authorities were the same as those who sat on the session). Ferreting out sin and punishing the transgressors was not the session's only

\footnotetext{
${ }^{3}$ G. Desbrisay, "Twisted by Definition: Women Under Godly Discipline in Seventeenth Century Scottish Towns," in Twisted Sisters: Women, Crime, and Deviance in Scotland Since 1400, eds. Y. Brown and R. Ferguson (East Linton: Tuckwell Press, 2002), 138.

${ }^{4}$ A. Glaze, "Women and Kirk Discipline: Prosecution, Negotiation, and the Limits of Control," Journal of Scottish Historical Studies 36.2 (2016): $126,128$.
} 
responsibility, as it also, among several other duties, oversaw poor relief, declared days of fasting and prayer, took care of the physical structure of the parish kirk, registered births, marriages, and deaths, and was responsible for bringing in new ministers. ${ }^{5}$ Unpaid laymen known as elders controlled kirk sessions and there were typically a dozen to twenty or more of them in each session. Yearly elections ensured frequent turnover of membership, and only very rarely did anyone refuse the honor of being made an elder, as the position granted a great deal of social prestige and authority. ${ }^{6}$ While the parish minister also sat on the session, his vote did not count any more than the other members. Membership of the session, while typically dominated by the wealthy and prominent, embraced a broad cross-section of Scottish society and included merchants, the landed, and craftsmen alike. These were male-dominated courts, as women were excluded from the role of kirk elder. Nevertheless, women played an important role in the sessions' duties, as their testimony was accepted and relied on exclusively in certain situations, especially in cases of adultery, fornication, and unwed mothers. ${ }^{7}$

Kirk sessions were vitally important to solidifying the connection between the laity and the post-Reformation Calvinist church in Scotland. As Margo Todd has argued, kirk sessions provided "social services" that worked toward creating "peace and orderliness" in Scottish society and built "a base of community support for a system that otherwise might have been construed as distastefully invasive and innovative." "Since the sessions were filled with laymen from a broad cross-section of Scottish society, and the sessions' membership, which provided a degree of prestige and

\footnotetext{
${ }^{5}$ For more on post-reformation kirk sessions see: Margo Todd, The Culture of Protestantism in Early Modern Scotland (New Haven: Yale University Press, 2002), ch. 1; John McCallum, Reforming the Scottish Parish: the Reformation in Fife, 1560-1640 (Burlington, VT: Ashgate, 2010), 153-188; Walter Makey, The Church of the Covenant, 1637-1651 (Edinburgh: John Donald, 1979); Graham, The Uses of Reform, ch. 2, 3, 6; D. Mullan, Scottish Puritanism, 1590-1638 (Oxford: Oxford University Press, 2000).

${ }^{6}$ Todd, Culture of Protestantism, 8-13.

${ }^{7} \mathrm{M}$. Todd, Culture of Protestantism, 8-13.

${ }^{8}$ Todd, Culture of Protestantism, 23.
} 
authority to their members, was frequently turned over, it can be assumed that the concerns of the session reflected the broader concerns of the middle-ranking male householders that dominated session membership.

While sexual sin was always a major concern of kirk sessions, it is clear from the kirk session records in the years immediately preceding the Prayer Book Riots that there was an especial concern about a perceived increase in sexual sin due to the presence, in many Edinburgh parishes, of soldiers levied to serve in the armies of Denmark and Sweden in the ongoing Thirty Years' War. ${ }^{9}$ Between 1618 and 1648, an estimated 50,000 Scots were recruited into foreign armies, mostly those of Denmark and Sweden. The period 1625 to 1627 alone saw 12,400 recruited. These men passed through towns where they would gather to await transportation to the Continent and were mainly vagabonds and criminals and other individuals on the margins of society. Masterless men and vagabonds were frequently a source of concern and target for punishment by kirk sessions, but masterless men who became soldiers were given a special status, as they were essentially protected by the state from punishment or the collection of debts. The presence of these soldiers had a tremendous social impact and had the effect of disrupting local authority and autonomy and upsetting social harmony. Sometimes the soldiers were mere nuisances, engaging in petty theft and other minor transgressions. Other times they engaged in violence, either attacking the citizens of towns or inserting themselves into preexisting feuds. ${ }^{10}$

Beyond disrupting good order in localities, the presence of soldiers also increased anxieties about sexual transgressions, which particularly impacted women in the communities. The kirk session records, especially those in Edinburgh and its environs, from the several years prior to the Covenant show that women were frequently brought before the sessions for transgressions with soldiers such as fornicating, committing adultery, giving birth to bastards, and

\footnotetext{
${ }^{9}$ Steve Murdoch, "Introduction," in Scotland and the Thirty Years War, ed. S. Murdoch (Leiden: Brill, 2002), 11-14; A. Grosjean, An Unofficial Alliance: Scotland and Sweden, 1569-1654 (Ledien: Brill, 2001), 15. ${ }^{10}$ Jason White, "State Power, Local Authority, and War in Scotland, 1625-9," Journal of Scottish Historical Studies, 32.6 (2016): 82-8.
} 
prostitution. The women who appeared before the kirk session in this period can be placed in several categories. The first group included married women whose husbands had left the country to serve as soldiers, and who were typically brought before sessions when they took up with a new man. Secondly, there were women accused of fornication or adultery with soldiers, many of whom had departed for the Continent, leaving the women to face the kirk session alone. Next were the prostitutes who serviced soldiers. And lastly, there were the women who gave birth to illegitimate children, often after a soldier had left the country.

Women whose husbands left to fight on the Continent frequently caught the attention of the kirk session when they entered new relationships. For example, in the St. Nicholas parish in Aberdeen, Margaret Smith was accused of adultery with David Anderson. Smith's husband, Robert Davidson, was said to be "past out of this countrie as ane sojor." She had to pay a 40 pound fine and give penance for eight days in sackcloth. ${ }^{11}$ Many soldier's wives accused of adultery often protested that their husbands were dead. When accused of adultery before the Trinity College (Edinburgh) kirk session, Katherine Pearson protested that her husband was dead and that she was only guilty of fornication. She was either pregnant or had a child and the session was eager to find the father. ${ }^{12}$ On some occasions, a woman had proof that her husband was dead on the Continent and sought permission to marry someone new. For example, in the parish of Strathbogie in Aberdeenshire, Elspet Wilson asked for the benefit of marriage to a new man and showed proof that her husband had died eight years before in Germany. ${ }^{13}$ The sessions typically allowed the wives of soldiers accused of adultery to provide proof that their husbands were dead. For example, Elspeth Anderson's husband had gone to the wars and she was accused of adultery with one Captain Blair. She obtained proof that her husband

11 “Aberdeen St. Nicholas Session Records," 22 July 1638, NRS CH2/448/4, fo. 208.

12 "Minute Book Trinity College Kirk (NE Edinburgh Parish), 16261638," 29 July 1630, NRS CH2/141/1, fo. 49.

${ }^{13}$ John Stuart, ed., Extracts from the Presbytery Book of Strathbogie (Aberdeen: Spalding Club, 1843), 1. 
had died in the wars and her charge was reduced to fornication. ${ }^{14}$ Sessions often seemed open to reducing charges of adultery to fornication with proper documentation. Adam Gib and Margaret Fairbairn were accused of adultery by the Trinity College kirk session in Edinburgh in March of 1629. Gib was able to obtain a testimonial from a gentleman soldier in Colonel MacKay's regiment in Germany that Fairbairn's husband, Alexander Alexander, had died and was buried in the winter of 1627 in Hamburg. Therefore Gib and Fairbairn were guilty of fornication, not adultery, and the charges were reduced to fornication. However, Fairbairn was still jailed because she could not pay her fine. ${ }^{15}$

Fornication with soldiers was a bigger problem than adultery. Women frequently appear in kirk session registers for fornication with men listed in the session records as having titles like colonel or captain. In the Trinity College kirk session, Isobel Graham was brought in for fornicating with Colonel Alexander Hamilton, Alesone Staig for fornication with Captain Forbes (who confessed to being the father of her child), and Margaret Johnston for fornication with Captain Thomas Lindsay. ${ }^{16}$ Sometimes the men were listed anonymously as "ane sojor," perhaps indicating that the woman did not know his name, while other times the woman might have known the name but claimed that the man had left the kingdom. For example, in the Trinity College session, Katherine Henry, a relapsed fornicator, was put in the house of correction and banished from the town for fornicating "filthily" with "ane sojor," while Margaret Weir was accused of fornication with Andrew Oswall who was said to be "presentlie furth of this kingdome," and Helene Lindsay was accused of adultery with, among others, a "sojor." 17 In Kirkcaldy, Margaret Jameson confessed to fornication with Alexander Garline under

\footnotetext{
14 "North Leith Kirk Session Records," 15 March 1633, NRS CH2 621/1 (no pagination).

15 "Minute Book of the Trinity College Kirk," 9 July 1629, NRS CH2/141/1, fos. $39,41,43 \mathrm{v}$.

16 "Minute Book of the Trinity College Kirk," 31 December 1629, 6 October 1631, 14 December 1631, NRS CH2/141/1, fos. 45v, 57v, 58v. NRS CH2 621/1 27 December 1640. ${ }^{17}$ Ibid., 19 September 1633, 26 April 1632, 20 September 1632, fos. 74, $61 \mathrm{v}, 64 \mathrm{v}$.
} 
promise of marriage. Her punishment was continued until he "come home" - suggesting that he was probably abroad as a soldier. ${ }^{18}$

Women were more frequently subjected to punishment than men, which was at least in part because the men often left for the wars without satisfying the kirk for their sins. In Kirkcaldy in southern Fife, both Janet Davison and Allison Smyth were punished for fornication with men who had left town for the wars. ${ }^{19}$ In South Leith in 1629, Margaret Hill had a child in fornication with Alexander Forbes, "a souldier" who was nowhere to be found. She was instructed to produce a testification from him or else leave town. ${ }^{20}$ Janet Thomsone in South Leith was pregnant with the child of Alexander Wilands who was "absent of ye cuntrie," presumably as a soldier. She produced a letter in which he confessed to being the baby's father, but she was the only who could stand trial for the transgression. $^{21}$ Margaret Chisholm was brought before the Canongate session and confessed to fornication under promise of marriage with Henry Boyd "now in Bohemia as she alleges." 22 In the North Leith kirk session, women accused of adultery with absent men had to pay public repentance until the men came home, which was essentially a sentence to repentance in perpetuity if the man never returned. ${ }^{23}$ There was a similar situation in South Leith, where Isobel Perry confessed to fornication with Minge Williamson; she was to pay penance until "his home coming from the sea." ${ }^{24}$ Therefore, women were more likely to be punished for fornication than men, simply because many male fornicators left the country to go fight in wars on the Continent.

18 "Kirkcaldy Kirk Session Minutes," 30 June 1640, NRS CH2/636/34, fo. 420.

19 "Kirkcaldy Kirk Session Minutes," 22 November 1626, NRS CH2/636/34, fo. 167.

20 "South Leith Kirk Session Minutes," 20 August 1629, NRS CH2/716/3

(no pagination).

${ }^{21}$ Ibid., 7 February 1630.

22 "Canongate Kirk Session Minutes," 1 September 1620, NRS $\mathrm{CH} 2 / 122 / 2$, (no pagination).

23 "North Leith Kirk Session Records," NRS CH2/621/1, fo. 777, 13

October 1626, 3 April 1628 (pagination ends after folio 777).

24 "South Leith Kirk Session Minutes," 15 July 1630, NRS CH2/716/3. 
Prostitution was a major concern for sessions because soldiers provided ample demand for their services. Pandars, or bawdswomen who facilitated encounters between prostitutes and their clients - were of equal concern to sessions as prostitutes themselves. In Canongate in April 1624, Marion Crawford confessed to fornicating twice with the Laird of Lochinvar (Robert Gordon, who was involved in military matters in Scotland) in both Leith and Edinburgh. Marion confessed that Margaret Reid was her pandar. Margaret was brought in one week later when they discovered that she had written to Lochinvar requesting that he send her some money to get her out of ward. The session found her to be an "impenitent person" and put her in the jogs (a hinged collar put around the offender's neck and attached to a post) with a paper on her head. She was then banished from the congregation forever. ${ }^{25}$ However, this case also reveals that sessions could show leniency to those who manifested contrition for their actions. One week after being put in the jogs, Margaret came before the session to confess her sin in encouraging Marion to "whoredom and harlotry with the Laird of Lochinvar." She avoided being banished from the parish by doing so, and instead she was warned that if she were found engaging in pandary again she would be scourged and banished. Marion also appeared the same day and proclaimed herself a "new woman" who wanted to amend her life. She likewise got off with a warning not to do the same or face possible scourging. ${ }^{26}$ Margaret was brought in a year later for still keeping company with Lochinvar, at which point she voluntarily left the town for good. ${ }^{27}$

In the winter of 1630/1631 the Canongate kirk session uncovered a prostitution ring involving Lord Spynie, the kingdom's muster master in charge of organizing "wappenshawings" or yearly musters of able-bodied men. A woman named Jonat Neilson was brought before the session for fornication, where she confessed that Lord Spynie asked her to "bring some whore or women to him." Neilson confessed that she sent Helen Jackson, a servant, to Spynie, and that another time she sent Bessie Robertson to another man that she did

25 "Canongate Kirk Session Minutes," 16 April 1624; 23 April 1624, NRS $\mathrm{CH} 2 / 122 / 2$.

26 "Canongate Kirk Session Minutes," 20 April 1624, NRS CH2/122/2.

27 "Canongate Kirk Session Minutes," 22 April 1625, NRS CH2/122/2. 
not know. Neilson begged for forgiveness on her knees and the session sentenced her to spend a quarter of a year in a haircloth, warning that if she "be found abusing her own body or seducing any other to filthiness" she would be scourged and banished from the town and congregation forever. ${ }^{28}$ Neither the Laird of Lochinvar nor Lord Spynie were brought before the session for their parts in the prostitution ring, revealing how social status, and perhaps even gender, could shield offenders from the justice of the session.

Soldiers often stayed in boarding houses, which were often already under suspicion because of the number of people who came in and out of them, which could lead to accusations of fornication and adultery for the women who ran them. For example, Helen Lindsay, a married woman in Edinburgh, was accused of committing adultery with several men and also of receiving slanderous people into her house. One of these was a soldier "who was known to have lyne with her in bed... at night." ${ }^{29}$ In Canongate, during a period in 1620 when several women were brought before the session for fornicating with and being impregnated by soldiers who had left for Bohemia (indicating that there were a number of soldiers in the parish at the time), John Moffet and his wife Margaret Howmed were charged with resetting (receiving, harboring, or giving shelter to) "diverse persons infamous and suspected of whoredom." It is probable that the couple allowed prostitutes to use their boarding house at a time when soldiers would have made their services in high demand. ${ }^{30}$ One of the prostitutes the couple was alleged to have harbored, Grissell Short, "a notorious whore and thief and stealer of purses," was put in the jogs for eight hours and was burned on the cheek with the town seal. ${ }^{31}$

Boarding houses were a concern even if soldiers were not involved. In North Leith, Essie Donaldson was fined five pounds for receiving two fornicators, William White and Kirsten Guthry, into

28 “Canongate Kirk Session Minutes, 1629-1649," NRS CH2/122/3, 48.

29 "Minute Book of the Trinity College Kirk, 1626-1628," 26 April 1632, NRS CH2/141/1, fo. $61 \mathrm{v}$.

30 "Canongate Kirk Session Minutes," 8 September 1620, NRS $\mathrm{CH} 2 / 122 / 2$.

31 "Canongate Kirk Session Minutes," 21 September 1621, NRS

$\mathrm{CH} 2 / 122 / 2$. 
her house. She was instructed to remove them or face double the penalty. ${ }^{32}$ Katherine Guillaume was accused of resetting "slanderous persons suspect of hures and thieves" and put to ward for four days and warned that if she received any more "strangers or suspicious persons" in her home she would be banished from the parish and her property confiscated to the kirk's use. Isobell McGill was fined for resetting an adulterous couple in her house. ${ }^{33}$ Resetting was such a problem in Canongate that in March 1623 the session enacted a ten pound fine for taking in any "slanderous person nor a woman or harlot or whore within their houses." 34 Over the next year or so the session brought in several people for resetting. While both men and women were charged with the sin, there was a clear gendered aspect to the charge as almost all of those who were resetted were women, many of whom gave birth in the house of the person charged. For example, in March 1624 Hendrie Rea had to pay the 10 pound fine for resetting Jeanne Murray, who gave birth to a child in Rea's home. ${ }^{35}$

While both men and women were subjected to public punishment for their sexual sins - typically in the form of wearing sackcloth (or haircloth) or sitting on the stool of repentance in front of the congregation - women faced an extra layer of public humiliation in the form of carting (being pulled in a cart through town while others chastised them for their sins) and scourging or flogging. In many cases, women caught committing sexual sins (usually because they had given birth to a child with no father to be found) were banished from town and merely threatened with carting or scourging. In the Trinity College session, Katherine McKay confessed to giving birth to a child in adultery. She was banished from the town until she could verify her child's father, and she was threatened with carting should she return without it. ${ }^{36}$ In South Leith

32 "North Leith Kirk Session Records," 20 April 1621, NRS CH2/621/1, fo. 775 .

33 "North Leith Kirk Session Records," 7 February 1623, 11 April 1623, NRS CH2/621/1, fos. 794, 797.

34 "Canongate Kirk Session Minutes," 23 March 1623, NRS CH2/122/2.

35 “Canongate Kirk Session Minutes," 5 March 1624, NRS CH2/122/2.

36 "Minute Book of the Trinity College Kirk, 1626-1638," 3 May 1627, NRS CH2/141/1, fo. 17. 
Agnes Fewer could not produce the father of her child, Patrick Ramsey, who she said was out of the country. She was banished from the parish under the threat of branding her cheek and being scourged through town. ${ }^{37}$ Also in the Trinity College session, Jonet Murray, accused of being "trelapsed" in fornication (meaning having committed fornication three times with three different men), was banished from town and threatened with scourging should she return. ${ }^{38}$ Women who had sexual relations with soldiers were subjected to similar public scorn. Marjorie Tod in the St. Nicholas kirk in Aberdeen confessed to fornication with a soldier and as a result was carted through town with a paper on her head, banished, and anyone found harboring her was to be fined. ${ }^{39}$ In Canongate four women, described as "common, scourged, banished louns and common resetors, frequenters, and haunters with all other debauched persons" were put in the jogs and conveyed through town with papers on their heads and breasts. ${ }^{40}$ Ritualistic shaming events, such as cartings, provided moments where the community, male and female alike, could come together to publicly decry sinners and reinforce traditional morals.

\section{Section II: Women's Testimony and Role in Punishment of} Sins

While women, especially servant women, were brought before kirk sessions and punished more than men, women could also play an important role testifying before sessions and helping them find and punish sinners. ${ }^{41}$ An example from Trinity College shows how a servant woman could play an important role testifying against her social superior. On 24 May 1638 a servant woman named Margaret Dowrat was brought before the session and accused of committing

37 "South Leith Kirk Session Minutes," 27 July 1637, NRS CH2/716/3.

38 "Minute Book of the Trinity College Kirk," NRS CH2/141/1, fo. 22.

${ }^{39}$ NRS CH2/448/4, 209, 29 July 1638. Christian Andro received a similar penalty on 18 November 1638 for fornication with Andrew Bart who was "aff the countrie."

40 "Canongate Kirk Session Minutes," 2 April 1624, NRS CH2/122/2.

${ }^{41}$ John Harrison, "Women and the Branks in Stirling, c. 1600 to c. 1730,"

Scottish Economic and Social History 18, no. 2 (1998): 114-131 
adultery with her master John Stewart. She confessed to having "carnal copulation" with him and to becoming pregnant from the encounter. She claimed that when she told Stewart of the situation he "desired her to be silent, for if she would reveal it he would deny it and manswear (i.e. swear falsely against) her before all the sessions in Edinburgh." Margaret further claimed that Stewart's wife, Alisone Miller, asked her to go to the Canongate to obtain a drink "that the child should never come to perfection and so should never be known." The session instructed Margaret to pay the civil penalty, verify her child's father, and do penance to the kirk for adultery. ${ }^{42}$

However, the saga did not end there. Margaret claimed that another one of Stewart's servants, Janet Baxter, had attempted to facilitate her abortion. The session brought Baxter in to see what she knew about the alleged adultery. Interestingly enough, the session was not concerned about the alleged attempted abortion (perhaps because it did not happen), but they were more concerned about catching Stewart as an adulterer. Janet testified that she and Stewart's wife, Alisone Miller, had asked Margaret whether she were pregnant or not, to which Margaret answered she did not know. Janet and Alisone then examined Margaret's "paip heads" (nipples) and then "knew it assuredly and said to her you are as sure with child as ever we were." Janet further testified that she heard Stewart say several times that he would deny that he was the father of Margaret's child "before all the judges in the world." Janet also claimed that she heard Stewart say he would give Margaret money and transport her out of the town. ${ }^{43}$

A week later Stewart himself was brought before the session where he "constantly denied" committing adultery with Margaret. When the session asked him why he had sent Margaret away from his house, he said "she was here one day and she is now gone away, I know not." Eight days later the session brought Janet back in for further testimony. Janet then provided the whole story as she knew it. On the night before Whitsunday (Pentecost, the seventh Sunday after Easter), Stewart's wife Alesone was out of the house with their daughter Elspet, when Stewart called Margaret to his room to help him with his boots before he went to bed. Margaret was in the room

42 "Minute Book Trinity College Kirk," NRS CH2/141/1, fo. 98v.

43 "Minute Book of the Trinity College Kirk," NRS CH2/141/1, fo. 99. 
with Stewart for a half hour before she came out and offered Janet "sweeties from her purse and desired her to stay silent." The next morning Stewart came down and found Margaret "sitting very melanchiously," which she claimed was due to "evil speeches" she had with Janet. This must have been an attempt by Margaret to manipulate Stewart into reprimanding Janet, as he then told her that if she ever "by word or deed spoke of a particular that might disgrace his name he should cause scourge her from the Castle Hill to the Abbey [Edinburgh's High Street]." Janet then testified that on Whitsunday she and Margaret were sharing a bed when she woke in the middle of the night to find Margaret gone and that she heard the couple engaged "in the act of carnal copulation." Janet then confronted Margaret, who confessed to her sins. ${ }^{44}$ In this case the testimony of a servant woman against her master and social superior was welcomed and taken seriously by the male-dominated kirk session. Janet's testimony was male-sanctioned and deemed appropriate even though she was speaking against a man who was also her master. The case reveals that women's voices, under the right circumstances, had an important role to play in the calling out and punishing of sins deemed especially reprehensible like adultery.

A common woman's testimony was often important for finding sinners. In Kirkcaldy after Margaret Masterstone denied committing adultery with a "Northland gentleman," her servant Janet Brown was brought in to testify. Janet said that the gentleman came to the door of their house around 9:00 or 10:00 at night and when Janet asked her mistress where the man had gone she said "he is away long since." However, the next morning Janet saw the gentleman leaving her mistress's chamber. Janet further testified that Margaret offered her a new "walicot" (a woman's petticoat or undergarment) for her silence. The kirk session decided rather than punishing Margaret immediately they would wait until her husband "came over the water," perhaps an indication that he too had left to fight on the Continent. ${ }^{45}$

Women often played a key role in identifying other women who were of suspect morals. Sometimes this involved gossip, shaming,

44 "Minute Book of the Trinity College Kirk," NRS CH2/141/1, fo. 99v.

45 “Kirkcaldy Kirk Session Minutes," 19 March 1639, NRS CH2/636/34, fo. 394 . 
and flyting (quarreling or using abusive language). These disorderly words caught the attention of kirk sessions and town councils when either the spreading of gossip was countered, usually through a bill of complaint brought to the session or if the flyting ended up taking a violent turn, and there are many instances of women brought before authorities for "flyting and bluiding" after insults of "debauched, scourged loune" or "whore" were leveled. Women could also get into trouble for cursing and scolding men. ${ }^{46}$ For example, Agnes Smith was brought before the Canongate session for telling John Bartilmo that she would "rip up his gutis with ane knyff" for slandering her by accusing her of committing adultery. ${ }^{47}$ Even worse was a woman using physical violence against a man. Agnes Dunlap of North Leith was brought in for striking a man with a knife "to the effusion of his blood in great quantity." Since she had done this kind of thing before she was carted through the parish with the branks (a bridle used to punish scolds) on her head and warned that if she was ever caught within the bounds of the parish again she would be scourged. ${ }^{48}$ Also in North Leith Margaret Lockert was put in ward for eight days for striking Alexander Anderson with a staff on the waponshawing (muster) day. ${ }^{49}$

In Canongate in 1630 Marie Campbell brought a bill of complaint against Jonet Fowlar for calling her a "highland whore," "highland mere vagbond," "harlot whores midwife," and "other

${ }^{46}$ E. Ewan: “"Tongue You Lied': The Role of the Tongue in Rituals of Public Penance in Late Medieval Scotland," in The Hands of the Tongue: Essays on Deviant Speech, ed. E. D. Craun (Kalamazoo: Medieval Institute Publications, 2007), 115-36; E. Ewan, “'Divers Injurious Words': Defamation and Gender in Late Medieval Scotland," in History, Literature and Music in Medieval Scotland, ed. R. A. McDonald (Toronto: University of Toronto Press, 2002), 63-86; E. Ewan, "Crime or Culture? Women and Daily Life in Late Medieval Scotland," in Twisted Sisters: Women, Crime and Deviance in Scotland Since 1400, ed. Y. Brown and R. Ferguson (East Linton: Tuckwell Press, 2002), 117-36. 47 “Canongate Kirk Session Minutes," 7 January 1631, NRS CH2/122/3, fo. 48 .

48 "North Leith Kirk Session Records,"4 May 1621, NRS CH2/621/1, fo. 776.

49 "North Leith Kirk Session Records,"13 August 1619, NRS CH2/621/1, fo. 748 . 
injurious words and wild slanders." Campbell brought witnesses to testify to her good behavior and that they had heard Fowlar and her husband say these things. Fowlar and her husband brought several witnesses of their own. In the end the session told the two women to stay away from each other, pay a small fine, and ask on their knees for God's forgiveness. ${ }^{50}$ In North Leith, Allison Gravei was accused of calling Margaret Clark a "harlet hure" in front of witnesses. She was instructed to confess her sin on her knees, beg forgiveness from Margaret, and promise never to do it again "under the pain of severe punishment." ${ }^{51}$ Claire Hon accused Janet Riddell of being pregnant. When Claire could not prove it was true, she was instructed to pay a fine and ask Janet's forgiveness. ${ }^{52}$

Sessions typically had little patience for women who had developed reputations for flyting in public. In North Leith, Katherine Lawson and Essie Donaldson were brought before the kirk session complaining against one another. Katherine claimed that Essie called her "pyper's hure" (meaning a bagpiper, associated with the Highlands) while Essie claimed Katherine had called her a "common scourged piper's hure and would prove her to be a thief and a whore and a receiver of thieves." Both women had three witnesses confirming that each had said these words to the other. The session then considered how both of them had been "oft found flyting and scolding with their neighbors," so they were both put to ward for several days and warned that if they were found flyting with their neighbors again they would be put in the branks. ${ }^{53}$

Therefore, women's public voices were frequently constrained by male sanctioning. Women could play an important role in testifying against sinners before the session, even when those they were testifying against were their social and gender superiors.

50 "Canongate Kirk Session Minutes," 20 July 1630, NRS CH2/122/3, fo. $30 \mathrm{v}$.

51 "North Leith Kirk Session Records," 27 June 1623, NRS CH2/621/1, fo. 801 .

52 "North Leith Kirk Session Records," 6 May 1625, NRS CH2/621/1, fo. 826.

53 "North Leith Kirk Session Records," 8 January 1619, NRS CH2/621/1, fo. 740 . 
Women could participate in the public shaming of prostitutes and other notorious sinners, as in cases of cartings. However, when female voices were unsanctioned, as in cases of flyting and gossiping, women could be subjected to harsh punishments. Beyond this, there was a clear concern amongst male kirk session authorities for an increase in sexual sins caused by the presence of soldiers, for which women took the brunt of the punishment. As will be shown below, the concern about prostitution and sexual sin was easily transferred by male Presbyterian authorities to concerns about English-style changes to the Scottish kirk imposed by the Stuart monarchs, James VI and Charles I.

\section{Section III: The "Harlot Mother"-Gendered Language and the Kirk}

Like other churches in Europe, the language used in Scotland by ministers and laymen alike to describe the church was often gendered female, and the church was understood to be the bride of Christ. This was not unique to Scotland, as it was a Biblical metaphor. However, the use of this language in Scotland took a sharper edge as it was turned against the kirk and used to justify rebellion in the form of the Covenant. David Calderwood, a prominent critic of the doctrinal changes to the Scottish liturgy brought about by the Perth Articles, described the kirk as "our mother kirk." He used this metaphor in many of his printed polemics against the liturgical changes. For example, in 1624 he wrote that "our mother kirk, and her mother, the truth, are forsaken." He went on to describe how in the past the "mother kirk" was appareled in her finest dress-its doctrine, which was firmly rooted in the prophets and apostles (meaning that it was Biblically ordained). However, recent innovations, the "unsavory mixture of man's learning," had changed this, and now the firm Biblical foundation of the kirk had given way to the "sandy heaps of human wisdom." 54

Calderwood's gendered rhetoric was rather less vitriolic than many others. The gendering of the church female, and the belief that

${ }^{54}$ David Calderwood, An Epistle of a Christian Brother (Amsterdam: Successors of G. Thorp, 1624), 2, 8. 
it had been corrupted from a formerly pure state, led to the use of many sexual metaphors. David Mullan has shown that preachers in Scotland began to gender their language after the reintroduction of episcopacy and introduction of the Five Articles of Perth in the early seventeenth century. They saw these things as the reintroduction of popish impurity, and began to refer to the kirk as a "scarlet whore" or a "harlot." 55 Samuel Rutherford, a prodigious letter-writer and vocal critic of the Jacobean and Caroline changes to the Scottish kirk, spent most of the 1630s writing letters, many of them to upper-class women, expressing dismay that the Scottish kirk had transformed from a "pure bride" to a "harlot mother." ${ }^{56}$ For Rutherford and many others, the "leprous strumpet" that the Scottish kirk had become needed to be purified for Christ, the bridegroom's, ultimate return. Calderwood even compared what he described as the idolatry of the Jacobean kirk to fornication, because idolatry, not unlike fornication, often comes about due to "allurements and provocations." ${ }^{57}$ During the time of the Covenant, Archibald Johnston of Wariston ruminated in his diary on the twenty-third chapter of Ezekiel, how the Scottish kirk had, like Aholah and Aholibah, "play(ed) the harlot in times bygone," but was now journeying out of its "Egyptian" captivity of human invention. ${ }^{58}$ Old Testament prophets, who often equated idolatry and adultery, provided many of the metaphors that supporters of the Covenant used to support their movement.

The framers and promoters of the 1638 National Covenant saw it as an opportunity to bring the kirk back from its sinful and idolatrous ways. For many, the most apt metaphor for the kirk's journey from purity, to corruption, and back to purity was the harlot turning from her sexual promiscuity. Johnston, the main author of the Covenant, recorded his experience listening to a sermon promoting the Covenant delivered by Henry Rollock, a minister in

${ }^{55}$ Mullan, "Women in Scottish Divinity," 32.

${ }^{56}$ Bonar, ed., Letters of Samuel Rutherford (Edinburgh, 1891), 382.

${ }^{57}$ David Calderwood, The Reexamination of the Two Articles Abridged: to wit, of the communicants gesture in the act of receiving, eating and drinking and the observation of festival days (Holland: s.n., 1636), 26. ${ }^{58}$ Archibald Johnston, Diary of Johnston of Wariston, 1632-1639, ed. George Morrison Paul (Edinburgh: Edinburgh University Press, 1911), 343. 
Edinburgh, in April 1638 just two months after the Covenant was signed. Rollo read the Covenant in its entirety and then read from Jeremiah 3:1, which discusses how a man, even when he turns his wife away and she "play(s) the harlot with many lovers" and becomes "polluted," should still take her back. Rollo admonished his parishioners that "the Lord was recalling and reclaiming his people, especially this city of Edinburgh, fra their former whoredomes and idolatries, as on our backs and bellies, of authority in breaking the Sabbath by feasting, by receiving first the Perth Articles, and giving the examples to others." 59 Johnston noted that the sermon was greeted with widespread acclaim from the parishioners who held up their hands, called out, and wept (with a "heavenly harmony of sighs and sobs"). He went on to describe how "the spirit of the lord so filled the sanctuary, warmed the affections, melted the hearts, dissolved the eyes of all the people, men and women, poor and noble, as for an long time they stood still up with their hands up unto the Lord." ${ }^{60}$ His description of the sermon reveals two important things about the Covenant. First, that it was conceptualized in gendered terms, and in a way that most Scottish laymen would have been familiar with - the admonition of a harlot to turn from her sinful ways and return to purity. This concept was constantly reinforced by kirk sessions and the public displays of repentance that had become an important part of the fabric of day-to-day life in post-Reformation Scotland. Second, Johnston noted how the Covenant brought class and sex together-all equally participated in the public cry for the rehabilitation of the kirk.

Alexander Henderson, a leading Scottish theologian and coauthor (with Wariston) of the National Covenant, gave several sermons in the first few months of 1638 to support the National Covenant. One of his favorite biblical metaphors in this period was Rahab, the "harlot" from the book of Joshua who assisted Israelite spies in the city of Jericho. In a sermon preached in early 1638 on Hebrews 11:31, Henderson remarked that harlotry covered a wide variety of terms, "whether bodily, or spiritual, or idolatrous, or

59 Johnston, Diary, 1632-1639, 330.

${ }^{60}$ Johnston, Diary, 1632-1639, 331. 
whether it be fornication, or adultery . ..." ${ }^{61}$ In other words, a harlot was a convenient metaphor for the perceived spiritual decay of the Scottish church. Nevertheless, a harlot, like Rahab, could repent and assist the bringing in of the kingdom of God.

The use of harlot rhetoric to criticize the Scottish kirk only lasted from the Perth Articles to the immediate aftermath of the signing of the Covenant. Following the Covenant, especially during the period of the Bishops' Wars and the alliance with Parliament during the civil war period, the rhetoric of Scottish preachers shifted to justifications of the use of the sword, resistance to authority, and admonitions of steadfastness in the face of adversity. This is born out in a collection of sermons gathered by David Lindsay that ran from 1639 to 1643 . Many of these sermons were given by preachers, such as Henry Rollo, who earlier preached in support of the Covenant using gendered language. Nowhere in any of these sermons do the words "harlot," "whore," or even references to the kirk as the pure bride of Christ, appear to be found. ${ }^{62}$ Therefore, it is clear that the moment of calling out the kirk for its transgressions, a moment when women were given a degree of agency to participate, was fleeting. Once the concern moved beyond the naming and shaming of the "harlot mother," more traditionally male-dominated concerns, such as war and politics, took over, and women returned to their more traditional gender roles where their voices were constrained. Just as the planners of the riots had intended, while women made the initial move of calling out and shaming the "harlot mother," men quickly took over and the gendered norm was restored.

The pre-Covenanting period culminated in a large, female-led, riot against the introduction of an English-style prayer book in Scotland. Historians of the Covenanting period, beyond recognizing that women played a significant role in leading the Prayer Book Riot, have not typically explored the social context or agency behind

${ }^{61}$ A. Henderson, Sermons, Prayers, and Pulpit Addresses, eds. C. M. McMahon and T. B. McMahon (Coconut Creek, FL: Puritan Publications, 2012), 246.

62 "Sermons of David Lindsay," National Library of Scotland, Woodrow Folio vol. XL VIII. 
female leadership of the riots. ${ }^{63}$ However, more recently, Laura Stewart has provided the most thorough analysis of women's role and agency in the riots. ${ }^{64}$ Women taking an active role in public in patriarchal early modern societies, such as Scotland, was seen as a monstrous inversion of the gender norm. Men were to be the head of the body politic and women were to be their helpers and avoid speaking out of turn, especially in public. Women were expected to be humble, quiet, and submissive. However, there were moments when the voice of women could be a powerful tool, a way of using concepts of "misrule" and turning the world upside down to expose corruption and give voice to dissent. ${ }^{65}$ To be sure, as Stewart shows, the symbolism behind female leadership of the riot was complex and variegated. Women may have been at the forefront of the riots because it was believed that authorities would have been less prone to attack or arrest women. Furthermore, having women lead the demonstrations against the Prayer Book may have been a way of showing that the riots were simply protests and not an attempt at rebellion or revolution, which is how they may have been interpreted by authorities had men led the way. Finally, while women were shut out of positions of authority within the kirk - there were no female bishops, ministers, elders, or members of kirk sessions-they nevertheless were "invested heavily in the rituals and practices of the kirk" and were prominent participants in private Bible-reading and prayer meetings. Therefore, the women of 23 July were acting in defence of a style of worship they were deeply invested in. ${ }^{66}$

\footnotetext{
${ }^{63}$ David Stevenson recognizes that women took the lead on 23 July, that the riots were planned, and that "there was no shortage of women willing to take part," but makes no attempt to analyze why women took the lead, or what message this was meant to convey, D. Stevenson, The Scottish Revolution, 1637-1644 (Edinburgh: John Donald, 1973), 58-63. Maurice Lee does not go beyond recognizing that women participated in the riots, M. Lee, The Road to Revolution: Scotland under Charles I, 1625-37 (Urbana, IL, 1985), 209-213.

${ }^{64}$ Laura Stewart, Rethinking the Scottish Revolution: Covenanted Scotland, 1637-1651 (Oxford: Oxford University Press, 2016), 56-62.

${ }^{65}$ Natalie Davis, "Women on Top" in Society and Culture in Early Modern France (Stanford, CA: Stanford University Press, 1975), 146-51. ${ }^{66}$ Stewart, Rethinking, 56-62.
} 
The ecclesiastical controversy in Scotland that led to the 1637 riots can be traced to the reign of Charles I's father, James VI (James I of England), who slowly introduced changes to the Scottish kirk to make it more compatible with England. In 1618 James VI oversaw the implementation of the Five Articles of Perth, which, among other things, called for kneeling during communion, as was done in the English church. Women played a role in resisting the changes brought about by the Perth Articles. For example, Easter communion in Edinburgh in 1619 saw a great deal of confusion over whether members of the congregation were to kneel or stand to receive the elements. When one minister attempted to scold those who would not kneel, a "sillie handmaid" stopped his mouth. ${ }^{67}$ In 1622 several women "of the base sort" in Edinburgh refused to kneel for communion and received it sitting, contrary to the Perth Articles. ${ }^{68}$ The evidence of these two incidents, though fragmentary, reveals two things. First, that women were involved in resisting Stuart religious policy well before 1637 . Second, both observers noted the lower social status of the women involved. This is a theme that would continue in the accounts from contemporaries who witnessed the 1637 riot.

There are several accounts from contemporaries that describe the 1637 Prayer Book Riots. These sources vary in perspective from pro-Covenanters, to anti-Covenanters, to more neutral parties. The sources agree on four basic things. First, women were prominent in the riots, if not the leaders. Second, the women threw projectiles, probably stools and maybe stones, both inside and outside the High Kirk. Third, the women shouted curses and invectives at the bishop and dean, including accusations of bringing "popery" into the kirk. Fourth, the mob attacked, and maybe nearly killed, the Bishop of Edinburgh, who then escaped with his life in the coach of the Earl of Roxburgh. ${ }^{69}$

${ }^{67}$ David Calderwood, History of the Kirk of Scotland, vol. vii (Wodrow Society, 1842-1849), 359-60.

${ }^{68}$ D. Laing, ed., Original Letters Relating to the Ecclesiastical Affairs of Scotland (2 Vol., Edinburgh: Bannatyne Club, 1851), II, 712.

${ }^{69}$ Nearly every source, from anti-Covenanters such as John Spalding and Walter Balcanquhall, to Covenanters such as John Row, Robert Baillie, Archibald Johnston, and the Earl of Rothes generally agree on these 
But who were these women? Disparate sources, from Covenanters themselves to their opponents, agree that they were commoners. The Covenanters' opponents, such as John Spalding and Walter Balcanquhall alleged that the women were "rascall serving women" from the bottom rung of Scottish society. ${ }^{70}$ Balcanquhall, who was responsible for composing the king's "official" response to the riots and the Covenant, went on to allege that these were the "meaner sort" of women who kept places for their social superiors in the kirk, were a "base multitude," and the "scum and froth of the people" bent on overthrowing royal authority under the pretense of religion while profaning the Lord's day and the Lord's house. Balcanquhall's invective fit with the broader narrative that the regime of Charles I was attempting to establish about the Covenanters for propaganda purposes - that the women had been goaded into the riot by their social betters who were revolting against monarchical authority under the guise of religion.

Having women who were possibly servants but definitely commoners lead the demonstration against the new Prayer Book opened the Covenanters to the accusation that they were subverting not only the political hierarchy, but also, perhaps more dangerously, the gendered hierarchy as well. Even before the riots began, James Balfour of Denmilne, a staunch Presbyterian who nevertheless remained loyal to the king, warned an unnamed woman, who was in all probability part of the planning of the riots, that her behavior was "unwomanlike" and a "monstrous" subversion of the natural state of the body politic. ${ }^{71}$ Robert Baillie, a Covenanter, worried that leadership of the riots by female commoners would undermine "our good cause." " Servants, male or female, causing disturbances in

things. See for example John Row, The History of the Kirk of Scotland from the Year 1558 to August 1637 (Edinburgh: Wodrow Society, 1842), 409.

${ }^{70}$ John Spalding, Memorialls of the Trubels in Scotland and England: AD 1624-AD 1649 (Edinburgh: Spalding Club, 1850), vol. I, 79; Walter Balcanquhall, A Large Declaration Concerning the Late Tumults in Scotland (London: Robert Young, 1639), 23-6.

${ }^{71}$ Stewart, Rethinking, 56.

${ }^{72}$ Robert Baillie, The Letters and Journals of Robert Baillie, 1637-1662, vol. 1 (Edinburgh: Ballatyne Club, 1841), 7-10. 
church over the placement of stools was a serious enough problem in Edinburgh's Trinity College parish in February 1636 that the kirk session ordered that the preacher make it clear from the pulpit that any servant disturbing the peace over stools would be forced to make public penance for their "great offense of God and slander of his Christian church." 73 Therefore, it is clear that many in Scotland were uncomfortable with both women and servants speaking or behaving out of turn.

Therefore, it is not surprising that some Covenanters were reluctant to mention that the riots were led by women in their public and private statements about the riot. The Earl of Rothes, whose work "Historical Information" was intended to be read by elite politicians, simply noted that the bishops, through their intention to use the new Prayer Book, "provoked a number of the commons." 74 He made no mention of women or their social status. Archibald Johnston did not remark on either the gender or social status of the rioters. He simply noted in his diary that on that "black, doleful Sunday" there was "such an outcrying what be the people's murmuring, mourning, railing, stool casting, as the like was never seen in Scotland." 75 When Covenanters did mention the gender and social status of the rioters, they typically did not go into much detail. John Row, a longtime opponent to bishops and a committed Covenanter, described the rioters as common women but did not elaborate. ${ }^{76}$ Robert Baillie, who in 1637 was still on the fence about the burgeoning Covenanting movement before fully committing to it later on, described the women as "serving maids" who began a tumult "as was never heard of since the Reformation of the nation." 77

One particularly illuminating source comes from Henry Guthrie, a moderate who signed the National Covenant in 1638, but who would eventually be at odds with more radical Presbyterians over the issue of conventicles (private prayer meetings), which he saw as

73 "Minute Book of the Trinity College Kirk, 1626-1638," 2 February 1636, NRS CH2/141/1, fo. 93v.

${ }^{74}$ John, Earl of Rothes, A Relation of Proceedings Concerning the Affairs of the Kirk of Scotland (Edinburgh: Bannatyne Club, 1830), 3.

${ }^{75}$ Johnston of Wariston, Diary, vol I, 265.

${ }^{76}$ Row, History, 409.

${ }^{77}$ Baillie, Letters and Journals, vol. I, 18-9. 
incompatible with Presbyterianism. Guthrie described the participants as a "multitude of wives and serving women" who rose up and began the riot. This is one of the only sources in which the women were described as "wives" and not just "servants" or "commoners." He went on to elaborate that the decision to have women lead the riots had been reached at a conspiratorial meeting held in the Cowgate of Edinburgh in which prominent future Covenanters like Alexander Henderson and David Dickson along with their wives "and several other matrons" met and "recommended to them that they and their adherents might give the first affront to the Book, assuring them that men should afterwards take the business out of their hands."78 Guthrie's description of the planning and implementation of the anti-Prayer Book agitation stands apart from other contemporary descriptions of the riots. First, unlike Balcanquhall and Spalding, he was not opposed to the Covenant and therefore was not disposed to portraying it in a way that was intended to undermine it. Second, while he was a supporter of the Covenant, as a bishop who did not support conventicles, he was more of an outsider who had fewer reasons to obscure that the riots were intentionally led by common women. Third, his account was written several years after the event, and, unlike the Covenanting leadership such as Rothes and Johnston, he did not have an immediate political reason to downplay the role of women in the riots.

Since there is fragmentary evidence that corroborates much of Guthrie's description of the riots, scholars have typically followed his lead when analyzing the event. ${ }^{79}$ Therefore, the scholarly consensus is this: the riots were planned well in advance in secret meetings, where those in attendance conspired to make a public show against the implementation of the English-style prayer book in Scotland when there had been no recourse to either a National Assembly of the kirk or a Scottish Parliament. The leaders of the

${ }^{78}$ Henry Guthry, Memoirs of Henry Guthry, Late Bishop of Dunkeld in Scotland (London: Printed for WB and Sold by J. Nutt, 1702), 20.

79 J. M. Henderson, "An 'Advertisement' about the Service Book, 1637," Scottish Historical Review, 23 (1925-6), 199-204; Stevenson, "Conventicles in the Kirk, 1619-1637: The Emergence of a Radical Party," Records of the Scottish Church History Society, 18 (1973): 99114. 
riots were common women, probably the wives of prominent devout Presbyterians and other citizens of Edinburgh mixed in with servants. No matter their employment or laboring status, it can be assumed that these women were connected to the Edinburgh community of zealous Presbyterians who attended the conventicles where the riots were planned. Finally, the planners of the riots intended for women to start the agitation against the Prayer Book after which the men would take over. ${ }^{80}$

Therefore, women's behavior and public voices were severely constrained before the Covenant. Women were more frequently punished for sexual sins or for their language in public. Nevertheless, there were moments, with the sanctioning of male authority, where women could speak out. This typically came when the men of the kirk session needed the testimony of a woman to punish a sinnereven if this sinner were male or of a higher social status than the women testifying against them. In the meantime, male Scottish preachers in the years before the riot and Covenant began to attach sexual sins such as harlotry and sexual license to the kirk, making it ripe for public shaming and sanction. This provided a moment where, with the sanctioning of male authority, women could publicly speak out against the sins of the kirk - something they did in force in the Edinburgh Prayer Book Riots.

${ }^{80}$ Tim Harris, Rebellion: Britain's First Stuart Kings (Oxford: Oxford University Press, 2014), 369; Stevenson, Scottish Revolution, 56-61; L. Stewart, Urban Politics and the British Civil Wars: Edinburgh, 1617-53 (Leiden: Brill, 2006), 216-218. 